\title{
Prognostic significance of HIF-2 $\alpha$ expression on tumor infiltrating macrophages in patients with uterine cer- vical cancer undergoing radiotherapy
}

\author{
Takashi Kawanaka', Akiko Kubo', Hitoshi Ikushima', Toshiaki Sano², \\ Yoshihiro Takegawa ${ }^{3}$, and Hiromu Nishitani' \\ ${ }^{1}$ Department of Radiology, ${ }^{2}$ Department of Human Pathology, Institute of Health Biosciences, The \\ University of Tokushima Graduate School, and ${ }^{3}$ Department of Radiologic Technology, School of \\ Health Sciences, The University of Tokushima, Tokushima, Japan
}

\begin{abstract}
Hypoxia-inducible factor (HIF)-2 $\alpha$, a basic helix-loop-helix (bHLH)-PAS protein, is the principal regulator of the hypoxic transcriptional response. An immunohistochemical study reported strong HIF-2 $\alpha$ expression in the cytoplasm of tumor infiltrative macrophages (TIMs). Thus we assessed the expression of HIF-2 $\alpha$ in human cervical cancer tissue before radiation therapy and its relationship to the clinical outcome. Seventy three patients with histologically proven primary advanced squamous cell carcinoma of the uterine cervix underwent radiotherapy in Tokushima University Hospital after biopsy specimens were taken. Among 73 specimens stained for HIF-2 $\alpha, 53$ (72.6\%) exhibited HIF-2 $\alpha$ immunoreactivity in the TIMs. In only 5 of 73 cases, HIF-2 $\alpha$ immunoreactivity was observed in the nuclei of tumor cells. The HIF-2 $\alpha$ positive cell count ratio in TIMs was associated with disease-free survival (DFS) with the worst DFS $(p=0.024)$ being in cases in the group with a high positive cell count ratio. A high HIF-2 $\alpha$ positive cell count ratio in TIMs increased the risk of local recurrence $(p=0.0142)$. These findings might suggest that the ratio of the HIF-2 $\alpha$ positive cell in TIMs may be a new predictive indicator for prognosis before radiation therapy for uterine cervical cancer. J. Med. Invest. 55 : 78-86, February, 2008
\end{abstract}

Keywords : hypoxia, HIF-2 alpha, macrophage, uterine cervical cancer

\section{INTRODUCTION}

Hypoxia is an important factor in the progression of solid tumors and has been associated with various indicators of tumor angiogenesis as well as metastasis. The presence of widespread hypoxia in tumors has been associated with reduced survival

Received for publication October 24, 2007 ; accepted December $11,2007$.

Address correspondence and reprint requests to Takashi Kawanaka, M.D., Department of Radiology, Institute of Health Biosciences, The University of Tokushima Graduate School, Kuramoto-cho, Tokushima 770-8503, Japan and Fax : +81-88-633-7174. following radiotherapy, surgery and chemotherapy. In radiotherapy, for example, hypoxic tumor cells are significantly less responsive to radiotherapy than their well-oxygenated counterparts because the oxygen-derived free radicals needed to potentiate ionizing radiation-induced DNA damage are reduced or absent in hypoxic cells (1). In a number of human malignant tumors, hypoxia is associated with poor outcome irrespective of the treatment modality used (2-5).

HIF-1 and HIF-2 are two closely related protein complexes that activate transcription of target genes in response to hypoxia. HIF-1 consists of a heterodi- 
mer of HIF- $1 \alpha$ and HIF-1 $\beta$, identical to the previously identified aryl hydrocarbon nuclear translocator (ARNT). Both are members of a family of transcription factors, termed bHLH/PAS proteins, which control a variety of critical embryogenic and physiological events. An alternative dimerization partner for ARNT, which also transactivates genes via HIF DNA recognition sites, has been identified and termed endothelial PAS domain protein 1 (EPAS-1), HIF-1 $\alpha$-like factor (HLF), and mouse HIF-related factor (HRF). In keeping with its functional homology with HIF-1 $\alpha$, this protein has been termed HIF- $2 \alpha$. HIF- 2 consists of a heterodimer of HIF- $2 \alpha$ and HIF-1 $\beta$. Hypoxia, or genetic alterations of the hypoxia signalling cascade $(6,7)$ leading to the constitutive expression of HIF, could promote intense and chaotic neovascularization that facilitates tumour spread. It has now been firmly established that HIF has important roles in tumour progression. Several immunohistochemical analyses have indicated that HIF- $1 \alpha$ and HIF-2 $\alpha$ are overexpressed in primary and metastatic human cancers, and that the level of expression, either as a result of tumour hypoxia or genetic alterations, is correlated with tumour angiogenesis and patient mortality $(7,8)$.

HIF- $1 \alpha$ and HIF-2 $\alpha$ protein expression was mainly observed in nuclei of tumor cells in various human cancer cells. Talks, et al . reported strong HIF-2 $\alpha$ expression in the cytoplasm of tumor infiltrative macrophages (TIMs) (9). To our knowledge, there is no published report of HIF-2 $\alpha$ expression in TIMs in human uterine cervical cancer. Therefore, we assessed the expression of HIF-2 $\alpha$ in human cervical cancer and the relationship between its expression and clinical outcomes.

\section{MATERIALS AND METHODS}

\section{Patients}

A retrospective analysis was done on all records of patients with histologically proven primary advanced squamous cell carcinoma of the cervix in the Department of Radiology, Tokushima University Hospital. Between December 1992 and March 2002, 73 patients with primary advanced squamous cell carcinoma of the cervix underwent radiotherapy. The clinical stage distribution according to the International Federation of Gynecology and Obstetrics (FIGO) criteria (10) was as follows : Stage IB = 3 (4.1\%), Stage IIA = 3 (4.1\%), Stage IIB = $16(21.9 \%)$, Stage IIIA $=1(1.4 \%)$, Stage IIIB $=35(50 \%)$, Stage IVA $=7(9.6 \%)$ and Stage IVB = $8(11.0 \%)$. Patients were staged by use of chest radiography, intravenous pyelography (IVP), blood chemistry, cystoscopy, and rectosigmoidoscopy. Table 1 summarizes patient characteristics. Follow up and survival information was obtained from hospital records.

All patients had biopsy specimens taken pretreatment from the exposed tumor on the cervix of the uterus. All samples were immediately formalinfixed and embedded in paraffin.

Table 1. Patients characteristics and treatment methods

\begin{tabular}{llc}
\hline Number of patients & & 73 \\
\hline Age range (median, years old) & & $42-93,(70)$ \\
\hline Follow up period, range (median, month) & Squamouscell carcinoma & $7214,(30)$ \\
\hline Histological classification & Ib & 3 \\
\hline Stage (FIGO 1994) & IIa & 3 \\
& IIb & 16 \\
& IIIa & 1 \\
& IIIb & 35 \\
\hline Brachytherapy & IVa & 7 \\
\hline Concurrent chemotherapy & IVb & 8 \\
\hline Maintenance chemotherapy & LDR & 48 \\
& HDR & 25 \\
\hline
\end{tabular}




\section{Radiotherapy Technique}

For patients with primary advanced carcinoma of the cervix, radiotherapy consisting of a combination of intracavitary brachytherapy and external beam irradiation has been used in our department. Before August 1997, low dose rate intracavity brachytherapy (LDR) was delivered with a Cs137 source. From September 1997, high dose rate intracavity brachytherapy (HDR) was delivered with an Ir-192 source.

External radiation therapy was performed with $6 \mathrm{MV}$ X-rays using the anterior and posterior parallel opposing field technique. Five fractions weekly, with 1.8 or 2.0 Gy per fraction, were delivered to the midplane of the pelvis. The area of external radiation therapy included both the primary tumor and the regional lymph nodes. The fraction size was 1.8-2 Gy and total dose to the whole pelvis was 36-52 Gy (median $48 \mathrm{~Gy}$ ) in the LDR group with midline shielding at 15-40 Gy (median $38 \mathrm{~Gy}$ ), whereas in the HDR group the fraction size was 1.8-2 Gy and the total 40-50 Gy (median $45 \mathrm{~Gy}$ ), with midline shielding at 20-45 Gy (median $43 \mathrm{~Gy}$ ).

In the LDR group, we delivered the intracavitary irradiation either before or after external radiation therapy using a T.A.O manual afterloading application (11) with a Cs-137 source. The patient received 44-55 Gy (median $48 \mathrm{~Gy}$ ) to point A with the external radiation therapy being designed to bring the dose to a total of 50-70 Gy through use of a midline shield. In the HDR group, intracavitary irradiation was delivered after external irradiation using a Modified Manchester Applicator, an Ir-192 source with a remotely controlled after-loading system (RALS) without general anesthesia. Once per week, at $6 \mathrm{~Gy}$ per fraction, a total of 12-30 Gy was delivered to point $\mathrm{A}$.

\section{Adjuvant therapy}

Fourteen patients with locally advanced cancer received intra-arterial chemotherapy using the balloon occluded arterial infusion (BOAI) method and 5 patients received weekly cisplatin (CDDP) infusion as concurrent chemotherapy. A total of 29 patients underwent oral administration of fluorouracil or tegafur-uracil as maintenance chemotherapy. Maintenance chemotherapy was performed continuously for two years following radiation therapy.

\section{Immunohistochemical study}

A mouse monoclonal antibody (Mab), anti-EPAS-
1/HIF-2 $\alpha$ (EP190b ; Novus Biologicals, Littleton, $\mathrm{CO}$, USA), was generated and characterized as reported previously $(9,12)$. Immunostaining was performed according to the Labeled StreptAvidin-Biotin (LSAB) method (Dako, Carpinteria, CA, USA), using a streptavidin-biotin-horseradish peroxidase complex. Briefly, deparaffinized and rehydrated sections were treated with $0.3 \%$ hydrogen peroxide in methanol for $30 \mathrm{~min}$ at room temperature to block endogenous peroxidase activity. Antigen retrieval was achieved by a $750 \mathrm{~W}$ microwave in $10 \mathrm{mM}$ citrate buffer ( $\mathrm{pH}$ 6.0) for $15 \mathrm{~min}$. After blocking with $10 \%$ goat serum in PBS, sections were incubated with the first antibody, and the reaction was carried out at $4{ }^{\circ} \mathrm{C}$ overnight. All initial antibodies used for this study were tested for optimal dilutions, and a moderate dilution was determined for the best differentiation of tumor samples. We used $1: 400$ diluted EPAS-1 Mab $(1.125 \mu \mathrm{g} / \mathrm{ml})$. For immunohistochemical detection of macrophages, dilution of the Mabs anti-human CD68 (KP1, Novus Biologicals, Littleton, CO, USA) was done at $1: 800$. Reactions were visualized using the 3,3 '-diaminobenidine substrate chromogen system (DAB) (K3468, Dako, Carpinteria, CA, USA). All IHC slides were counterstained by Mayer's hematoxylin.

\section{Quantification of the Immunohistochemical study}

A quantification method for the TIMs and HIF-2 $\alpha$ in TIMs was based on a previous study $(13,14)$. To summarize, for focal macrophage quantification, all slides were first observed at low power magnification $(\times 10)$ to select three areas of the highest concentration of CD68. The numbers of positively stained cells in the three areas were counted at high power magnification $(\times 200)$. The average number of stained cells in the three 'hotspot' areas was considered as the CD68 count. The number of HIF-2 $\alpha$ positively stained cells in the same area of the three hotspots was counted at high power magnification $(\times 200)$. The average count was considered as the HIF- $2 \alpha$ count. The average of the HIF- $2 \alpha$ count was divided by the average of the CD68 count, and the HIF- $2 \alpha /$ CD68 ratio was obtained.

Assessment was performed in blinded fashion and independently by two investigators (T. K., A. K.). We used the average data from the two investigators. Conflicting scores were resolved by discussion over the microscope.

\section{Statistical analysis}

A computer software Stat View-J 5.0 statistical 
package (Abacus Concepts, Berkeley, CA, USA) was used for all statistical analysis and generation of survival curves. $\chi^{2}$ tests examined the relationships between categorical tumor variables. Spearmanrank correlations were used to investigate relationships between continuous patient and tumor variables. Survival curves were plotted using the method of Kaplan and Meier, and the Log-rank test was used to evaluate differences between life tables. $P$ values less than 0.05 were considered significant.

\section{RESULTS}

\section{HIF- $2 \alpha$ expression}

In only 5 of 73 samples, HIF-2 $\alpha$ immunoreactivity was observed in nuclei of tumor cells. All of these expressions were observed to be very weak at a high power field. No tumor cell contained immunoreactive cytoplasm (Fig. 1).
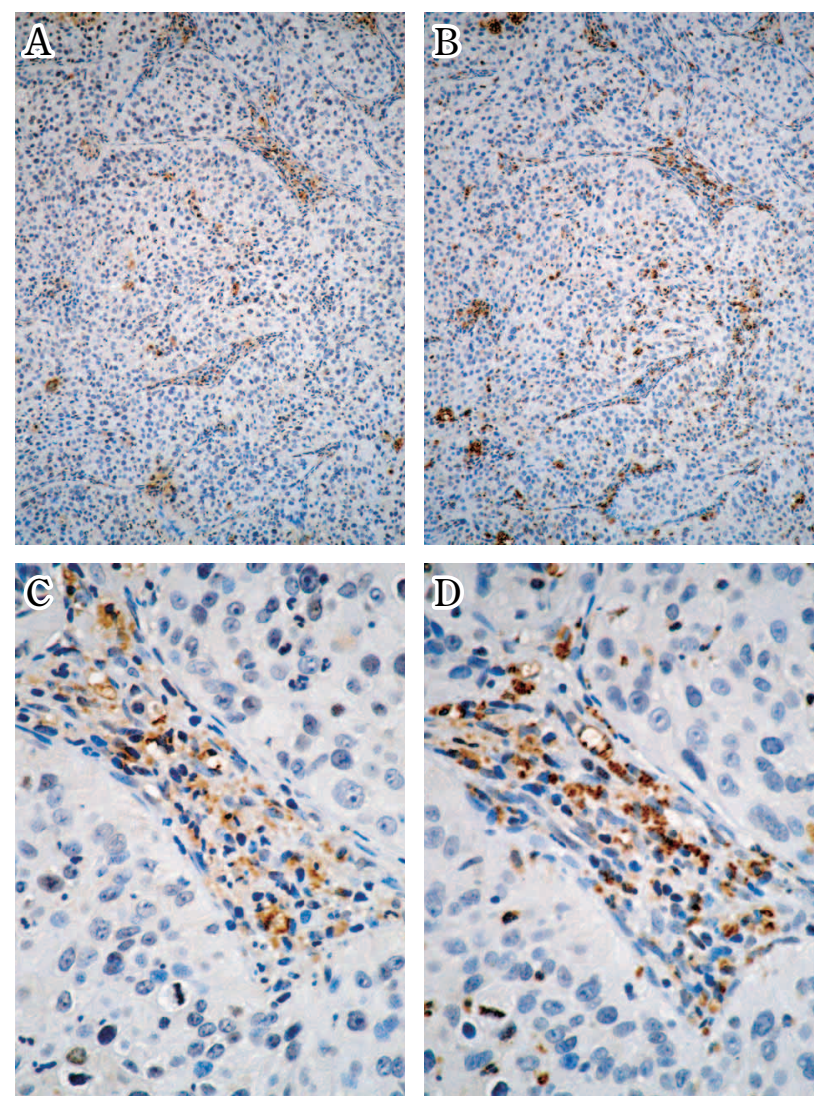

Fig. 1. Immunohistochemical study of HIF-2 $\alpha$ and CD68 at human invasive uterine cervical cancer (squamous cell carcinoma) On (A) HIF-2 $\alpha$ and (B) CD68 in low power field $(\times 10)$, the uterine cervical squamous carcinoma show common positive cells observed in mainly interstitial tissue. On (C) HIF-2 $\alpha$ and (D) CD68 in high power field $(\times 200)$, both immunoreactivity was detected in common mononuclear cells that are distributed mainly in interstitial tissue and slightly in tumor parenchyma. In this case, a few tumor cells show HIF-2 $\alpha$ immunoreactivity in nuclei.
CD68 immunoreactivity was detected in mononuclear cells that were distributed mainly in the interstitial tissue and slightly in the tumor parenchyma. These mononuclear cells were identified as TIMs (Fig. 1). HIF-2 $\alpha$ immunoreactivity in colocalization with CD68 immunoreactive cells was found in $53(72.6 \%)$ of the 73 samples. All the positive HIF$2 \alpha$ immunoreactivity in interstitial cells considered as TIMs was in the cytoplasm and was even stronger than that in tumor cells. The number of HIF- $2 \alpha$ counts in 73 samples ranged from 0 to 79 with a median value of 14 (mean=18.7, $\mathrm{SD}=16.8$ ), which was used as the cutoff point for categorical analysis. A group of 39 fell into the high HIF- $2 \alpha$ count category (53\%). The number of CD68 counts in 73 samples ranged from 0 to 169 with a median value of 57 (mean=62.4, SD=35.1). The high CD68 count group contained 38 samples (52\%) using the cutoff point of 57. A positive correlation was found between increasing CD68 count (as a continuous variable) and increasing HIF-2 $\alpha$ count (Spearman Rho $=0.54, \mathrm{p}<0.0001$ ). The HIF- $2 \alpha / \mathrm{CD} 68$ ratio ranged from $0 \%$ to $100 \%$ with a median value of $23.2 \%$ (mean $=29.2 \%, \mathrm{SD}=25.7)$.

\section{HIF-2 $\alpha$ expression and clinical futures}

In this study, the cumulative overall 5-year local control rate according to stage was $100 \%$ in stage I, $89 \%$ in stage II, $78 \%$ in stage III, $43 \%$ in stage IVa and $25 \%$ in stage IVb. The cause-specific 5-year survival rate was $100 \%$ in stage I, $79 \%$ in stage II, $58 \%$ in stage III, $43 \%$ in stage IVa and $13 \%$ in stage IVb. These data show similar results to previous reports on radiotherapy outcomes of uterine cervical cancer from other institutes (15-18). Table 2 shows the dis-

Table 2. Distribution of HIF-2 $\alpha, \mathrm{CD} 68$ and HIF-2 $\alpha / \mathrm{CD} 68$ in FIGO classification

\begin{tabular}{|c|c|c|c|c|c|c|}
\hline & \multirow[b]{2}{*}{$\mathrm{n}$} & \multicolumn{5}{|c|}{ FIGO classification } \\
\hline & & I & II & III & IVa & $\mathrm{IVb}$ \\
\hline \multicolumn{7}{|l|}{ HIF-2 $\alpha$ counts } \\
\hline \multicolumn{7}{|l|}{$($ median = 14/HPF $)$} \\
\hline HIF- $2 \alpha<14$ & 34 & 3 & 8 & 17 & 4 & 2 \\
\hline HIF- $2 \alpha \geqq 14$ & 39 & 0 & 11 & 19 & 3 & 6 \\
\hline \multirow{2}{*}{\multicolumn{7}{|c|}{$\begin{array}{l}\text { CD68 counts } \\
\text { (median }=57 / \mathrm{HPF})\end{array}$}} \\
\hline & & & & & & \\
\hline CD68 $<57$ & 35 & 2 & 11 & 16 & 3 & 3 \\
\hline $\mathrm{CD} 68 \geqq 57$ & 38 & 1 & 8 & 20 & 4 & 5 \\
\hline \multicolumn{7}{|l|}{$\begin{array}{l}\text { HIF-2 } \alpha \text { / CD68 ratio } \\
(\text { median }=23.2 \%)\end{array}$} \\
\hline HIF- $2 \alpha /$ CD $68<23.2$ & 35 & 3 & 7 & 21 & 2 & 2 \\
\hline HIF- $2 \alpha / \mathrm{CD} 68 \geqq 23.2$ & 38 & 0 & 12 & 15 & 5 & 6 \\
\hline
\end{tabular}


tribution of HIF-2 $\alpha$ count, CD68 count and HIF-2 $\alpha$ / CD68 ratio in the FIGO classification. There were relatively balanced distributions of classified HIF- $2 \alpha$ count, CD68 count and HIF-2 $\alpha / \mathrm{CD} 68$ ratio in the FIGO classification.

The HIF- $2 \alpha$ count, CD68 count and HIF- $2 \alpha$ / CD68 ratio were compared with DFS and causespecific survival (CSS). The HIF-2 $\alpha$ count and CD68 count failed to achieve significance for either DFS or CSS (Fig. 2 and 3). Only the HIF-2 $\alpha /$ CD68 ratio was associated with DFS ( $p=0.024)$ with cases in the high category group having the worst DFS (Fig. 4). However the HIF-2 $\alpha /$ CD68 ratio was not associated with CSS. The distribution of the HIF-2 $\alpha$ / CD68 ratio is shown in Table 3 . There was no correlation between the HIF-2 $\alpha / \mathrm{CD} 68$ ratio and age, con-
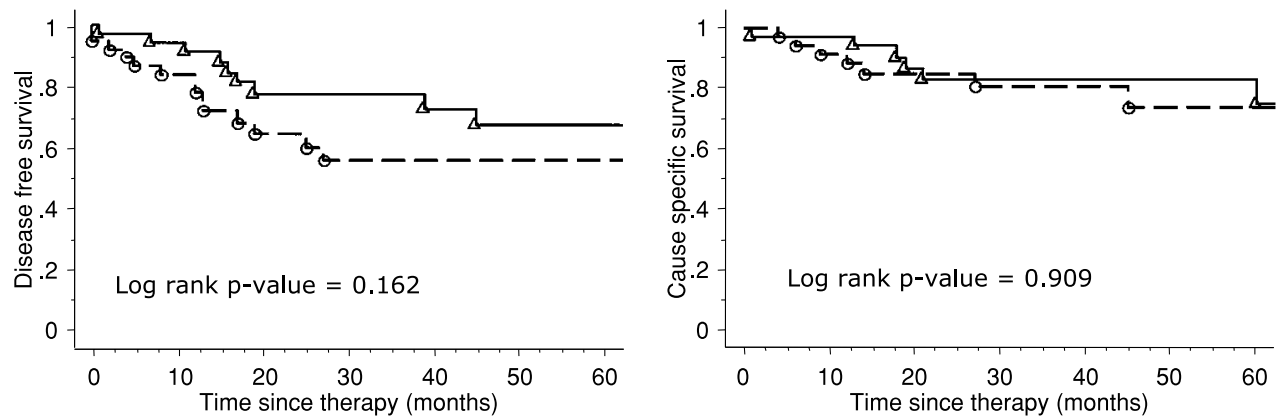

$$
---\operatorname{HIF}-2 \alpha \geqq 14 \quad \mathrm{n}=38
$$

HIF- $2 \alpha<14 \quad n=35$

Fig. 2. Kaplan-Meier curves of DFS and CSS based on HIF-2 $\alpha$ expression in TIMs
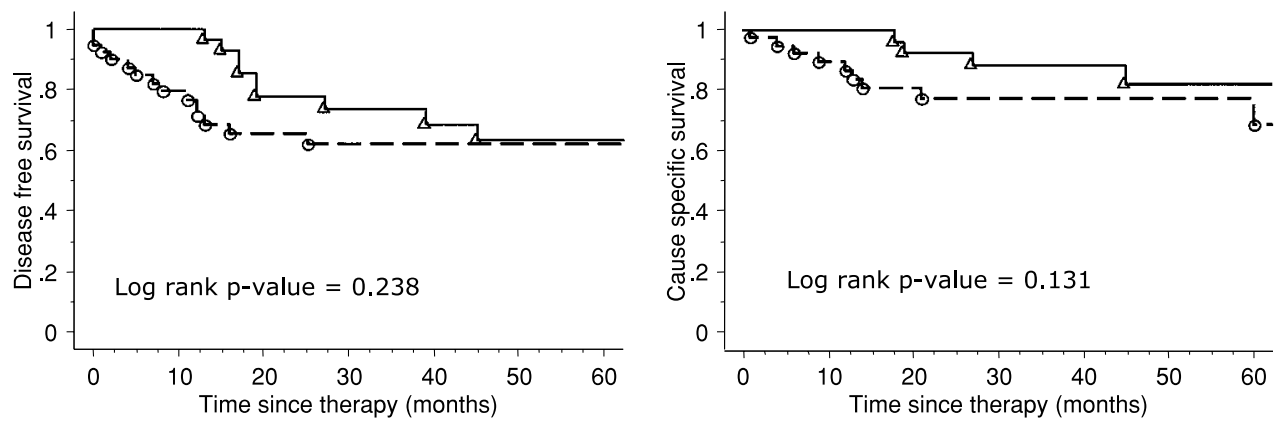

$--\operatorname{CD} 68 \geqq 55 n=40$

CD68 $<55 n=33$

Fig. 3. Kaplan-Meier curves of DFS and CSS based on CD68 expression in TIMs
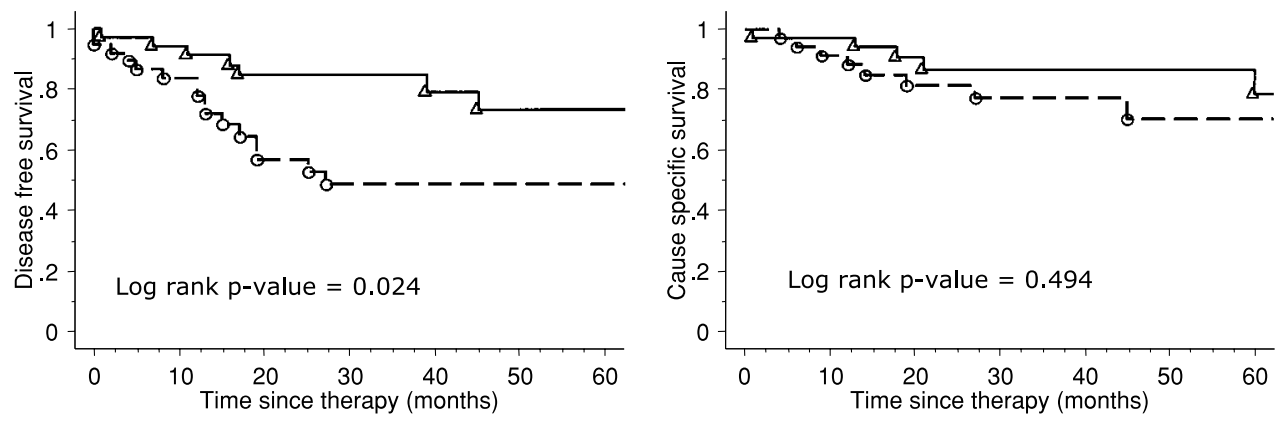

$---\mathrm{HIF}-2 \alpha / \mathrm{CD} 68 \geqq 22 \mathrm{n}=38$
$\mathrm{HIF}-2 \alpha / \mathrm{CD} 68<22 \mathrm{n}=35$

Fig. 4. Kaplan-Meier curves of DFS and CSS based on HIF-2 $\alpha / C D 68$ ratio 
Table 3. Distribution of HIF-2 $\alpha / \mathrm{CD} 68$ ratio

\begin{tabular}{|c|c|c|c|c|c|}
\hline & & \multirow[b]{2}{*}{$\begin{array}{c}\text { Over all } \\
(\mathrm{n}=73)\end{array}$} & \multicolumn{2}{|c|}{ HIF-2 $\alpha /$ CD68 ratio (\%) } & \multirow[b]{2}{*}{$P$ value } \\
\hline & & & $\begin{array}{l}<23.2 \\
(\mathrm{n}=35)\end{array}$ & $\begin{array}{l}\geqq 23.2 \\
(\mathrm{n}=38)\end{array}$ & \\
\hline Age $($ mean $\pm \mathrm{SD})$ & & $70.3 \pm 11.2$ & $71.5 \pm 12.0$ & $70.8 \pm 10.8$ & $\mathrm{p}=0.794$ \\
\hline \multirow[t]{2}{*}{ Concurrent chemotherapy } & With & 19 & 11 & 8 & \multirow{2}{*}{$\mathrm{p}=0.317$} \\
\hline & without & 54 & 24 & 30 & \\
\hline \multirow[t]{2}{*}{ Brachytherapy } & LDR & 48 & 25 & 23 & \multirow{2}{*}{$\mathrm{p}=0.227$} \\
\hline & HDR & 25 & 10 & 15 & \\
\hline \multirow[t]{2}{*}{ Maintenance chemotherapy } & With & 29 & 15 & 14 & \multirow{2}{*}{$\mathrm{p}=0.590$} \\
\hline & without & 44 & 20 & 24 & \\
\hline $\begin{array}{l}\text { Pretreatment hemoglobin level, } \\
\text { mean } \pm \mathrm{SD}\left(/ \mathrm{mm}^{3}\right)\end{array}$ & & $11.4 \pm 1.9$ & $11.1 \pm 2.1$ & $11.6 \pm 1.8$ & $\mathrm{p}=1.094$ \\
\hline $\begin{array}{l}\mathrm{CD} 68 \text { count, } \\
\text { mean } \pm \mathrm{SD}(/ \mathrm{HPF})\end{array}$ & & $61.5 \pm 35.6$ & $58.2 \pm 39.7$ & $64.6 \pm 31.6$ & $\mathrm{p}=0.437$ \\
\hline
\end{tabular}

current or maintenance chemotherapy, brachytherapy method, pretreatment hemoglobin level or CD68 count. HIF-2 $\alpha$ immunoreactivity in the nuclei of tumor cells had no relationship with DFS or CSS. (Data not shown)

In 19 of 73 patients tumors have recurred during our observation period. The high HIF-2 $\alpha / \mathrm{CD} 68$ ratio group had a significantly increased risk of local recurrence $(\mathrm{p}=0.0142)$ (Table 4$)$.

Table 4. Treatment failure pattern

\begin{tabular}{lcc}
\hline & \multicolumn{2}{c}{ HIF-2 $\alpha /$ CD68 ratio (\%) } \\
\cline { 2 - 3 } & $\begin{array}{c}<23.2 \\
(\mathrm{n}=35)\end{array}$ & $\begin{array}{c}\geqq 23.2 \\
(\mathrm{n}=38)\end{array}$ \\
\hline Local only & 2 & 7 \\
Distant (With local) & $5(1)$ & $5(1)$ \\
\hline Overall & 7 & 12 \\
\hline
\end{tabular}

\section{DISCUSSION}

To our knowledge, this is the first report about HIF-2 $\alpha$ in squamous cell carcinoma of the uterine cervix. Major findings in this survey were that most of the HIF-2 $\alpha$ immunoreactivity in squamous cell carcinoma of the uterine cervix was detected in TIMs and the percentage of HIF- $2 \alpha$ immunoreactivity in TIMs significantly correlated with DFS.

It is well established that, when exposed to lowered levels of oxygen, tissues compensate in a variety of ways, ranging from systemic adjustments caused by increased erythropoietin production to tissue-specific effects of increased VEGF expression and the largely cellular effects of increased glycolysis (19). All of these adaptations to hypoxia are regulated wholly or in part by the HIF complex. The oxygen-regulated components of this complex are the HIF- $\alpha$ subunits. To date, three members of the HIF- $\alpha$ family have been cloned : HIF- $1 \alpha$, HIF- $2 \alpha$, and HIF-3 $\alpha$. Of the three HIF- $\alpha$ subunits, the most extensively characterized subunit regarding function is HIF-1 $\alpha$. Its hypoxia-induced stabilization and the following induction of a number of target genes seems to be a general response in most, if not all, cells. In addition, these proteins have at least some unique functions as revealed by their different target genes (20-24). By contrast, HIF-3 $\alpha$ is involved in downregulation of the hypoxic response via an alternatively spliced transcription factor, which may function as an inhibitor of HIF-1 $\alpha(25,26)$.

HIF-1 $\alpha$ and HIF- $2 \alpha$ expression are a significant prognostic factor of various cancers treated by radiotherapy (12, 27-30). In uterine cervical cancer, some papers (31-34) reported that overexpression of HIF- $1 \alpha$ in pretreatment uterine cervical cancer cells served as a predictive marker for poor prognosis after treatment by radiotherapy. However, there has been no study examining the relationship between the expression of HIF-2 $\alpha$ and uterine cervical cancer. In this study, weak HIF-2 $\alpha$ immunoreactivity in tumor cells was observed in only five biopsy sections and was not associated with prognosis. This difference in immunoreactivity between HIF-1 $\alpha$ and HIF-2 $\alpha$ in cervical cancer cell seems to indicate that there are individual variations in the hypoxic response. Findings relating to the role of TIMs in cervical cancers have been controversial. It has been noted that there are higher 
macrophage counts in invasive carcinomas as opposed to cervical squamous intraepithelial lesions (35). In turn, squamous intraepithelial lesions contain more macrophages than the normal cervix (36). Davidson, et al . (37) looked at 75 cases of carcinoma, staining the tissue with CD68 and two endothelial markers, and evaluated the cases by light microscopy. Based on previous reports of an association between TIM density, increased angiogenesis, and poorer outcome in breast carcinoma (38), these authors sought to evaluate the same in cervical cancer. No correlation was found between TIM count and tumor stage, grade, or survival, nor with microvessel count.

Leek, et al. reported that HIF-2 $\alpha$ expression in TIMs was not associated with DFS but was marginally associated with overall survival in cases in the high expression group which had worse survival in invasive breast cancer (39). To our knowledge, this was the only report which mentioned a correlation between HIF-2 $\alpha$ expression in TIMs and clinical outcome. However in this study, HIF-2 $\alpha$ expression in TIMs was associated with DFS. Additionally there was a significant tendency for an increased risk of local recurrence in cases with a high HIF-2 $\alpha$ expression in the TIM group. This recurrence pattern suggests that the role of HIF-2 $\alpha$ expression in TIMs is more important in regional tumor development than in distant metastasis. It seems that HIF-2 $\alpha$ secreted by TIMs is a very important key factor in tumor survival. Thus if we can control TIM behavior, it must then contribute to remission of the tumor.

In conclusion, we evaluated HIF-2 $\alpha$ expression in uterine cervical cancer. Most of the HIF- $2 \alpha$ expression was observed in TIMs and a high HIF-2 $\alpha$ expression ratio in TIMs was associated with DFS and local recurrence. These results demonstrated that macrophages recruited into tumor tissue play a role in promoting tumor growth and that HIF- $2 \alpha$ expression in TIMs is an important prognostic factor, especially for predicting future local recurrence after radiotherapy in patients with advanced uterine cervical cancer.

\section{ACKNOWLEDGMENTS}

We thank Ms. Noriko Amou, Department of Human Pathology, Institute of Health Biosciences, The University of Tokushima Graduate School, for excellent advice for Immunohistochemical technique.

\section{REFERENCES}

1. Vaupel P, Kelleher DK, Hockel M : Oxygen status of malignant tumors : pathogenesis of hypoxia and significance for tumor therapy. Semin Oncol 28 : 29-35, 2001

2. Hockel M, Knoop C, Schlenger K, Vorndran B, Baussmann E, Mitze M, Knapstein PG, Vaupel $\mathrm{P}$ : Intratumoral pO2 predicts survival in advanced cancer of the uterine cervix. Radiother Oncol 26 : 45-50, 1993

3. Hockel M, Schlenger K, Aral B, Mitze M, Schaffer U, Vaupel P : Association between tumor hypoxia and malignant progression in advanced cancer of the uterine cervix. Cancer Res 56 : 4509-4515, 1996

4. Fyles AW, Milosevic M, Pintilie M, Hill RP: Cervix cancer oxygenation measured following external radiation therapy. Int J Radiat Oncol Biol Phys 42 : 751-753, 1998

5. Brizel DM, Scully SP, Harrelson JM, Layfield LJ, Bean JM, Prosnitz LR, Dewhirst MW : Tumor oxygenesion predicts for the likelihood of distant metastasis in human soft tissue sarcoma. Cancer Res 56 : 941-943, 1996

6. Isaacs JS, Jung YJ, Mole DR, Lee S, TorresCabala C, Chung YL, Merino M, Trepel J, Zbar B, Toro J, Ratcliffe PJ, Linehan WM, Neckers $\mathrm{L}$ : HIF overexpression correlates with biallelic loss of fumarate hydratase in renal cancer : novel role of fumarate in regulation of HIF stability. Cancer Cell 8 : 143-153, 2005

7. Kim WY, Kaelin WG : Role of VHL gene mutation in human cancer. J Clin Oncol 22 : 49915004, 2004

8. Semenza GL : Targeting HIF-1 for cancer therapy. Nat Rev Cancer 3 : 721-732, 2003

9. Talks KL, Turley H, Gatter KC, Maxwell PH, Pugh CW, Ratcliffe PJ, Harris AL: The expression and distribution of the hypoxia-inducible factors HIF-1alpha and HIF-2alpha in normal human tissues, cancers, and tumor-associated macrophages. Am J Pathol 157 : 411-421, 2000

10. Pecorelli S, Benedet JL, Creasman WT, Shepherd JH : FIGO staging of gynecologic cancer. 1994-1997 FIGO Committee on Gynecologic Oncology. International Federation of Gynecology and Obstetrics. Int J Gynaecol Obstet 65 : 243-249, 1999

11. Tazaki E, Arai T, Oryu S : An applicator for intracavitary radiation therapy of carcinoma of the uterine cervix. Jpn J of Clin Radiol 10 : 768- 
775,1965

12. Koukourakis MI, Giatromanolaki A, Skarlatos J, Corti L, Blandamura S, Piazza M, Gatter KC, Harris AL : Hypoxia inducible factor (HIF-1a and HIF-2a) expression in early esophageal cancer and response to photodynamic therapy and radiotherapy. Cancer Res $61: 1830-1832$, 2001

13. Maeda K, Chung YS, Ogawa Y, Takatsuka S, Kang SM, Ogawa M, Sawada T, Onoda N, Kato Y, Sowa M : Thymidine phosphorylase/ platelet-derived endothelial cell growth factor expression associated with hepatic metastasis in gastric carcinoma. Br J Cancer 73 : 884-888, 1996

14. Matsumura M, Chiba Y, Lu C, Amaya H, Shimomatsuya T, Horiuchi T, Muraoka R, Tanigawa $\mathrm{N}$ : Platelet-derived endothelial cell growth factor/thymidine phosphorylase expression correlated with tumor angiogenesis and macrophage infiltration in colorectal cancer. Cancer Lett 128 : 55-63, 1998

15. Barillot I, Horiot JC, Pigneux J, Schraub S, Pourquier H, Daly N, Bolla M, Rozan R: Carcinoma of the intact uterine cervix treated with radiotherapy alone: a French cooperative study : update and multivariate analysis of prognostics factors. Int J Radiat Oncol Biol Phys 38 : 969-978, 1997

16. Logsdon MD, Eifel PJ : Figo IIIB squamous cell carcinoma of the cervix : an analysis of prognostic factors emphasizing the balance between external beam and intracavitary radiation therapy. Int J Radiat Oncol Biol Phys 43 : 763-775, 1999

17. Lanciano RM, Won M, Coia LR, Hanks GE : Pretreatment and treatment factors associated with improved outcome in squamous cell carcinoma of the uterine cervix : a final report of the 1973 and 1978 patterns of care studies. Int J Radiat Oncol Biol Phys 20 : 667-676, 1991

18. Pedersen D, Sogaard H, Overgaard J, Bentzen SM : Prognostic value of pretreatment factors in patients with locally advanced carcinoma of the uterine cervix treated by radiotherapy alone. Acta Oncol 34 : 787-795, 1995

19. Semenza GL: Regulation of mammalian $\mathrm{O} 2$ homeostasis by hypoxia-inducible factor 1 . Annu Rev Cell Dev Biol 15 : 551-578, 1999

20. Hu CJ, Wang LY, Chodosh LA, Keith B, Simon $\mathrm{MC}$ : Differential roles of hypoxia-inducible factor 1 alpha (HIF-1 alpha) and HIF-2 alpha in hy- poxic gene regulation. Mol Cell Biol 23 : 93619374, 2003

21. Brusselmans K, Bono F, Maxwell P, Dor Y, Dewerchin M, Collen D, Herbert JM, Carmeliet $\mathrm{P}$ : Hypoxia-inducible factor-2 alpha (HIF-2alpha) is involved in the apoptotic response to hypoglycemia but not to hypoxia. J Biol Chem 276 : 39192-39196, 2001

22. Park SK, Dadak AM, Haase VH, Fontana L, Giaccia AJ, Johnson RS : Hypoxia-induced gene expression occurs solely through the action of hypoxia-inducible factor 1alpha (HIF-1alpha) : role of cytoplasmic trapping of HIF-2alpha. Mol Cell Biol 23 : 4959-4971, 2003

23. Carmeliet P, Dor Y, Herbert JM, Fukumura D, Brusselmans K, Dewerchin M, Neeman M, Bono F, Abramovitch R, Maxwell P, Koch CJ, Ratcliffe P, Moons L, Jain RK, Collen D, Keshert E: Role of HIF-1alpha in hypoxiamediated apoptosis, cell proliferation and tumour angiogenesis. Nature 394 : 485-490, 1998

24. Sowter HM, Raval RR, Moore JW, Ratcliffe PJ, Harris AL : Predominant role of hypoxiainducible transcription factor (Hif)-1alpha versus Hif-2alpha in regulation of the transcriptional response to hypoxia. Cancer Res 63 : 6130-6134, 2003

25. Makino Y, Kanopka A, Wilson WJ, Tanaka H, Poellinger L : Inhibitory PAS domain protein (IPAS) is a hypoxia-inducible splicing variant of the hypoxia-inducible factor-3alpha locus. J Biol Chem 277 : 32405-32408, 2002

26. Hara S, Hamada J, Kobayashi C, Kondo Y, Imura $\mathrm{N}$ : Expression and characterization of hypoxia-inducible factor (HIF)-3alpha in human kidney : suppression of HIF-mediated gene expression by HIF-3alpha. Biochem Biophys Res Commun 287 : 808-813, 2001

27. Kaanders JH, Wijffels KI, Marres HA, Ljungkvist AS, Pop LA, van den Hoogen FJ, de Wilde PC, Bussink J, Raleigh JA, van der Kogel AJ : Pimonidazole binding and tumor vascularity predict for treatment outcome in head and neck cancer. Cancer Res 62 : 7066-7074, 2002

28. Aebersold DM, Burri P, Beer KT, Laissue J, Djonov V, Greiner RH, Semenza GL: Expression of hypoxia-inducible factor-1alpha : a novel predictive and prognostic parameter in the radiotherapy of oropharyngeal cancer. Cancer Res 61 : 2911-2916, 2001

29. Hui EP, Chan AT, Pezzella F, Turley H, To KF, Poon TC, Zee B, Mo F, Teo PM, Huang DP, 
Gatter KC, Johnson PJ, Harris AL : Coexpression of hypoxia-inducible factors 1alpha and 2alpha, carbonic anhydrase IX, and vascular endothelial growth factor in nasopharyngeal carcinoma and relationship to survival. Clin Cancer Res 8 : 2595-2604, 2002

30. Koukourakis MI, Giatromanolaki A, Sivridis E, Simopoulos C, Turley H, Talks K, Gatter KC, Harris AL: Hypoxia-inducible factor (HIF1A and HIF2A), angiogenesis, and chemoradiotherapy outcome of squamous cell head-andneck cancer. Int J Radiat Oncol Biol Phys 53 : 1192-1202, 2002

31. Hutchison GJ, Valentine HR, Loncaster JA, Davidson SE, Hunter RD, Roberts SA, Harris AL, Stratford IJ, Price PM, West CM : Hypoxiainducible factor 1alpha expression as an intrinsic marker of hypoxia : correlation with tumor oxygen, pimonidazole measurements, and outcome in locally advanced carcinoma of the cervix. Clin Cancer Res 10 : 8405-8412, 2004

32. Ishikawa H, Sakurai H, Hasegawa M, Mitsuhashi N, Takahashi M, Masuda N, Nakajima M, Kitamoto Y, Saitoh J, Nakano T : Expression of hypoxic-inducible factor 1alpha predicts metastasis-free survival after radiation therapy alone in stage IIIB cervical squamous cell carcinoma. Int J Radiat Oncol Biol Phys 60 : 513521,2004

33. Bachtiary B, Schindl M, Potter R, Dreier B, Knocke TH, Hainfellner JA, Horvat R, Birner $\mathrm{P}$ : Overexpression of hypoxia-inducible factor 1alpha indicates diminished response to radiotherapy and unfavorable prognosis in patients receiving radical radiotherapy for cervical cancer. Clin Cancer Res 9 : 2234-2240, 2003

34. Burri P, Djonov V, Aebersold DM, Lindel K,
Studer U, Altermatt HJ, Mazzucchelli L, Greiner $\mathrm{RH}$, Gruber G : Significant correlation of hypoxiainducible factor-1alpha with treatment outcome in cervical cancer treated with radical radiotherapy. Int J Radiat Oncol Biol Phys 56 : 494501, 2003

35. Davidson B, Goldberg I, Kopolovic J : Inflammatory response in cervical intraepithelial neoplasia and squamous cell carcinoma of the uterine cervix. Pathol Res Pract 193 : 491-495, 1997

36. al-Saleh W, Delvenne P, Arrese JE, Nikkels AF, Pierard GE, Boniver J : Inverse modulation of intraepithelial Langerhans' cells and stromal macrophage/dendrocyte populations in human papillomavirus-associated squamous intraepithelial lesions of the cervix. Virchows Arch $427: 41-48,1995$

37. Davidson B, Goldberg I, Gotlieb WH, LernerGeva L, Ben-Baruch G, Agulansky L, Novikov I, Kopolovic J : Macrophage infiltration and angiogenesis in cervical squamous cell carcinoma- clinicopathologic correlation. Acta Obstet Gynecol Scand 78 : 240-244, 1999

38. Leek RD, Lewis CE, Whitehouse R, Greenall M, Clarke J, Harris AL : Association of macrophage infiltration with angiogenesis and prognosis in invasive breast carcinoma. Cancer Res 56 : 4625-4629, 1996

39. Leek RD, Talks KL, Pezzella F, Turley H, Campo L, Brown NS, Bicknell R, Taylor M, Gatter KC, Harris AL: Relation of hypoxiainducible factor-2 alpha (HIF-2 alpha) expression in tumor-infiltrative macrophages to tumor angiogenesis and the oxidative thymidine phosphorylase pathway in Human breast cancer. Cancer Res 62 : 1326-1329, 2002 